\title{
Cognitive presentation of multiple sclerosis: evidence for a cortical variant
}

\author{
M Zarei, S Chandran, A Compston, J Hodges
}

J Neurol Neurosurg Psychiatry 2003;74:872-877

See end of article for authors' affiliations

.....................

Correspondence to: Professor John Hodges, MRC Cognition and Brain Sciences Unit, 15 Chaucer Road, Cambridge CB2 2EF, UK john.hodges@ mrc-cbu.cam.ac.uk

Received 19 June 2002 In final revised form 7 February 2003

Accepted

7 February 2003
A hough once considered uncommon or late features, cognitive and neuropsychiatric symptoms are now well recognised as early manifestations of multiple sclerosis. ${ }^{1-5}$ Estimates vary but Lyon-Caen and colleagues reported that $85 \%$ of patients with clinically definite multiple sclerosis of less than two years' duration, and $66 \%$ of those with only optic neuritis, showed some form of cognitive impairment. ${ }^{6}$ Similarly, Swingler and Compston ${ }^{7}$ reported a prevalence of $40 \%$ for neuropsychiatric symptoms and signs in 301 patients with established multiple sclerosis during routine clinical interview. Others have since confirmed this observation and reported that the prevalence of symptoms such as memory deficit or depression and focal cortical syndromes was as high as $60 \% .^{3-5}$

Despite the recognised high prevalence of cognitive symptoms in early established multiple sclerosis, ${ }^{8-11}$ presentation with predominant or pure cognitive or neuropsychiatric symptoms is rarely described. In a retrospective study, Skegg ${ }^{12}$ identified 91 patients with multiple sclerosis in a prevalent population of 112 000: of 29 with neuropsychiatric manifestations, $18(62 \%)$ had been initially referred for psychiatric assessment, often several years before the diagnosis of multiple sclerosis. In addition, there have been eight previous reports of an exclusive neuropsychiatric or cognitive presentation of multiple sclerosis, four detailing single cases, and the collective experience amounting to 17 individuals. ${ }^{13-20}$

We report six patients with multiple sclerosis who presented with predominant cognitive or neuropsychiatric syndromes or both. We suggest that, together with emerging pathological and radiological evidence for discrete cortical involvement in multiple sclerosis, these clinical observations suggest a subclass of multiple sclerosis in which the cerebral cortex is predominantly or exclusively involved. Self evidently, the availability of emerging treatment opportunities highlights the importance of early recognition of cortical multiple sclerosis.

\section{METHODS}

\section{Patients and diagnostic criteria}

This was a retrospective study of six cases that were referred to the memory and cognitive disorders clinic at Addenbrooke's Hospital, Cambridge, between 1996 and 2001. All patients had an undiagnosed cognitive/neuropsychiatric syndrome at initial presentation and were ultimately found to have multiple sclerosis. All cases fulfilled recently revised diagnostic criteria of multiple sclerosis. ${ }^{1}$

\section{History and examination}

Information about handedness, education, occupation, risk factors for cognitive disorders (for example, thyroid disorders) or white matter diseases (such as vaculitides), other medical history, psychiatric background, drug history, and family history was collected. A detailed neurological examination was undertaken.

After evaluation by a behavioural neurologist $(\mathrm{JH})$ in the memory clinic, all patients were also referred to a senior neurologist with an interest in multiple sclerosis (AC) for assessment of the clinical and paraclinical evidence and confirmation of the diagnosis of multiple sclerosis. The patients were followed up for between two and five years thereafter.

\section{Investigations}

To exclude other causes of cognitive impairment or white matter disease, a comprehensive series of investigations was carried out. Blood tests included urea and electrolytes, erythrocyte sedimentation rate, full blood count, vitamin B-12 and 


\section{Table 1 Demographic and clinical summary of the cases described}

\begin{tabular}{|c|c|c|c|c|}
\hline Case & Age/sex & Initial symptoms & Paraclinical findings & Follow up \\
\hline 1 & $47 / F$ & $\begin{array}{l}2 \text { year history: progressive amnesic syndrome, } \\
\text { emotional lability and depression. }\end{array}$ & $\begin{array}{l}\text { VER: delayed } \\
\text { CSF: OCB + } \\
\text { MRI: diffuse and marked cerebral } \\
\text { atrophy } \\
\text { Brain biopsy: very mild } \\
\text { hypercellularity and moderate } \\
\text { diffuse microglial activation with no } \\
\text { evidence of vasculitis, } \\
\text { leucodystrophy, or progressive } \\
\text { multifocal leucoencephalopathy } \\
\text { Neuropsychology: impaired } \\
\text { retrograde memory, poor verbal } \\
\text { fluency, anomia, and dyscalculia }\end{array}$ & $\begin{array}{l}3 \text { years; spastic paraplegia, dysarthria, } \\
\text { optic atrophy, and urinary incontinence; } \\
\text { wheelchair-bound, full time care, severe } \\
\text { cognitive impairment }\end{array}$ \\
\hline 2 & $52 / \mathrm{F}$ & $\begin{array}{l}3 \text { year history: depressive illness + progressive } \\
\text { amnesic syndrome; difficulty in autobiographical and } \\
\text { semantic memory and face recognition }\end{array}$ & $\begin{array}{l}\text { VER: delayed } \\
\text { CSF: OCB+ } \\
\text { MRI: periventricular high signal } \\
\text { changes } \\
\text { SPECT: bilateral }(R>L) \text { hypoperfusion } \\
\text { of posterior parietal cortices } \\
\text { Neuropsychology: dyscalculia, } \\
\text { dysgraphia, visuo-constructive and } \\
\text { visuo-spatial dysfunction, impaired } \\
\text { anterograde and retrograde memory }\end{array}$ & $\begin{array}{l}4 \text { years; optic atrophy, continued to } \\
\text { deteriorate cognitively }\end{array}$ \\
\hline 3 & $60 / F$ & $\begin{array}{l}5 \text { year history: progressive amnesia, inattention, and } \\
\text { personality changes }\end{array}$ & $\begin{array}{l}\text { VER: normal } \\
\text { CSF: OCB- } \\
\text { MRI: cortical atrophy with multiple } \\
\text { high signal lesions in white matter } \\
\text { SPECT: marked hypoperfusion of } \\
\text { cortical perfusion particularly in } \\
\text { frontal regions } \\
\text { Neuropsychology: anterograde } \\
\text { and retrograde memory impairment, } \\
\text { reduced digit span, reduced verbal } \\
\text { fluency, and mild arithmetic and } \\
\text { visuospatial difficulty }\end{array}$ & $\begin{array}{l}2 \text { years; cerebellar ataxia, INO, } \\
\text { bladder involvement, blindness, and } \\
\text { progressive cognitive impairment }\end{array}$ \\
\hline 4 & $38 / \mathrm{F}$ & $\begin{array}{l}15 \text { months history: progressive amnesic syndrome and } \\
\text { difficulty in writing, reading, spelling, use of words } \\
\text { associated with depression, and later ataxia and alien } \\
\text { limb phenomenon }\end{array}$ & $\begin{array}{l}\text { VER: delayed } \\
\text { CSF: OCB- } \\
\text { Brain MRI: marked cortical atrophy } \\
\text { with widespread periventricular high } \\
\text { signal lesions } \\
\text { Brain biopsy: no evidence of } \\
\text { vasculitis, leucodystrophy, or } \\
\text { progressive multifocal } \\
\text { leucoencephalopathy } \\
\text { Neuropsychology: severe } \\
\text { impairment of retrograde memory, } \\
\text { comprehension, attention, working } \\
\text { memory, and verbal fluency together } \\
\text { with marked executive dysfunction, } \\
\text { constructional apraxia, and } \\
\text { pervasive psychomotor retardation } \\
\text { but normal visual-perceptual skills }\end{array}$ & $\begin{array}{l}18 \text { months; severely demented, without } \\
\text { verbal communication, blind, spastic } \\
\text { quadriparesis, doubly incontinent and } \\
\text { required full care }\end{array}$ \\
\hline 5 & $42 / F$ & $\begin{array}{l}4 \text { year history: recurrent depression, before signs and } \\
\text { symptoms of cerebellar dysfunction }\end{array}$ & $\begin{array}{l}\text { VER: delayed } \\
\text { CSF: OCB+ } \\
\text { MRI: bilateral high signal changes in } \\
\text { the cerebrum, corpus callosum, and } \\
\text { cerebellum } \\
\text { Neuropsychology: impairment of } \\
\text { anterograde and semantic memory } \\
\text { and poor abstract reasoning }\end{array}$ & $\begin{array}{l}2 \text { years; developed INO, spastic } \\
\text { paraparesis, marked cerebellar signs } \\
\text { and bladder instability, as well as } \\
\text { progressive amnesic syndrome }\end{array}$ \\
\hline 6 & $57 / M$ & $\begin{array}{l}3 \text { year history: depression, episodes of confusion, } \\
\text { disorientation, delusional ideation, memory } \\
\text { impairment, preceding an episode of ataxia, double } \\
\text { vision and unilateral facial palsy }\end{array}$ & $\begin{array}{l}\text { VER: normal } \\
\text { CSF: OCB+ } \\
\text { MRI: marked cortical atrophy with } \\
\text { widespread periventricular high } \\
\text { signal lesions } \\
\text { SPECT: hypoperfusion of both } \\
\text { frontal and temporal regions } \\
\text { Neuropsychology: impaired verbal } \\
\text { fluency and anterograde memory } \\
\text { suggestive of fronto-temporal } \\
\text { dysfunction }\end{array}$ & $\begin{array}{l}3 \text { years; bilateral pyramidal signs with } \\
\text { extensor plantar response; severe } \\
\text { cognitive deterioration requiring nursing } \\
\text { home care }\end{array}$ \\
\hline
\end{tabular}

CSF, cerebrospinal fluid; F, female; M, male; MRI, magnetic resonance imaging; OCB, oligoclonal bands; INO, internuclear ophthalmoplegia; VER, visual evoked response. 
folate levels, C reactive protein, antibody screen (ANA, ANCA, anti-dsDNA, ENA, anti-Yo, anti-Ro, anti-La, antigliadin, antiphospholipid, and antithyroid antibodies), short synacthen test, and white cell enzymes. Cerebrospinal fluid (CSF) examination consisted of protein, glucose, angiotensin converting enzyme level, oligoclonal band, and viral and microbiological studies (including JC virus). Radiological examination included chest $x$ ray, brain and spinal cord magnetic resonance imaging (MRI), and in some cases single photon emission computed tomography (SPECT). Patients also had electroencephalography and visual evoked response (VER) examinations. Two underwent brain biopsy. Table 1 shows presenting symptoms, later progression, and results of relevant investigations.

\section{Neuropsychology}

All patients underwent a detailed neuropsychological evaluation using a battery of tasks designed to evaluate premorbid and current intellectual abilities, anterograde visual and verbal episodic and working memory, naming, reading, executive and attentional abilities, and visuospatial and perceptual functions. As the patients presented over a period of almost a decade, the tests employed differed between cases and it is not possible to present raw data in a meaningful way. In all cases, however, statements regarding patterns of impairment are based on a comparison with established normative data.

\section{RESULTS}

We describe six cases, five female and one male, aged 38 to 60 years at the time of presentation. None of the cases had the initial sensory or motor symptoms typically seen in multiple sclerosis at the time of referral. Three of these cases (Nos 2, 5 , and 6) had a long course of depression preceding cognitive impairment. In four cases (Nos 1, 2, 3, and 4) dementia was characterised by a progressive amnesic syndrome. Case 4 presented with distinct pure cortical dysphasia, dysgraphia, and dyslexia in the context of an amnesic syndrome. All patients became demented on follow up, severely enough to require full time care. Disability in two patients (Nos 2 and 4) was essentially cognitive. Case 2 never developed any significant physical disability and case 4 developed a mild physical impairment. The four other cases developed severe physical disability: two became blind (Nos 3 and 4) and four (Nos 1, 3 , 4 , and 5) developed urinary sphincter involvement.

Four cases (Nos 1, 3, 4, and 6) had cerebral atrophy. Brain MRI scan of case 1 did not show high signal changes in the white matter. Two cases (Nos 3 and 6 ) had normal VER. Two cases (Nos 4 and 3) were negative for CSF oligoclonal band. Other aspects of CSF examination were unremarkable in all cases. All other laboratory investigations, in particularly vasculitis screen, immunological profile, and search for evidence of leucodystrophy, were entirely normal. Details of each patient's clinical presentation and their laboratory findings are shown in table 1.

The diagnosis of multiple sclerosis was often delayed for several years after the initial presentation. In five of our six cases depression and progressive dementia were prominent features. Our case series shows that patients with cortical multiple sclerosis can remain free from physical manifestations of the disease for many years (case 2), follow a relapsing-remitting course (case 6), or show a primary progressive pattern (cases 3 and 5).

\section{DISCUSSION}

A cognitive or psychiatric presentation of multiple sclerosis appears to be rare. This is surprising considering the overall frequency of neuropsychiatric symptoms at all stages of multiple sclerosis. It may reflect underdiagnosis, as most physicians habitually depend on the presence of physical symptoms before considering the diagnosis of multiple sclerosis. The true prevalence of this variant is therefore probably underestimated.

In previous reports documenting 17 cases (table 2), the patients' ages at presentation ranged from 19 to 43 years, with a female predominance as expected, in a clinical series of patients with multiple sclerosis. The diagnosis of multiple sclerosis was made within weeks to 10 years of the initial neuropsychiatric presentation. Depressive and amnesic syndromes were the most common symptoms, occurring in 14 and nine cases, respectively. Two of these case reports ${ }^{19}{ }^{14}$ had acute presentations; the rest were indolent for many years before classic symptoms and signs of multiple sclerosis appeared. Neuropsychological data on previously reported cases are limited, making it difficult to derive a pattern of neuropsychological deficit from these patients; however, reduced verbal IQ and amnesia appear to be the most common findings.

The presentation of our patients and their clinical course is broadly consistent with other published reports. We found depression and amnesia to be the most common neuropsychiatric presentations of multiple sclerosis. Semiological and neuropsychological analysis of all the cases show a consistent pattern of neuropsychiatric symptoms, including amnesia, aphasia, dyscalculia, dyslexia, dysgraphia, dyspraxia, and visuospatial disabilities. This consistency leads us to suggest that most of these symptoms could largely be attributed to cortical dysfunction. Clinical, radiological, and pathological evidence to support this contention is presented below.

\section{Depression and cortical dysfunction in multiple sclerosis} Depression is well recognised as a complication of multiple sclerosis, with an estimated lifetime prevalence of almost $50 \%{ }^{21}$ There is evidence that depression represents a feature of multiple sclerosis rather than simply a reaction to the disease or comorbidity in a study controlled for physical disability. ${ }^{22}$ The present and previous series suggest that multiple sclerosis can be heralded by a long period of depression ( 13 of 17 cases in previous case reports, and five of the six in the present series).

As in many other neurological disorders, depression in multiple sclerosis is commonly thought to reflect white matter pathology. Depression can, however, be associated with pathology affecting the orbital and medial prefrontal cortices. ${ }^{24} \mathrm{Sev}-$ eral studies into the biology of depression have shown that depressive symptoms, both in primary affective disorders and in association with organic neurological disease, are associated with reduced temporal and frontal cortical function. ${ }^{25-27}$ Dysfunction of these structures may also result in impairment of language, memory, or executive processes. Interestingly these symptoms were recognised in our case series as well as in those reported previously (table 2 ). A recent study of the anatomical correlation of cortical lesions and depression in multiple sclerosis using SPECT and MRI showed an association between reduction of perfusion in orbital, mesial temporal, and anterior and posterior cingulate cortices and depressive symptoms, but with no lesion load in the white matter..$^{28}$ More recently, depression in multiple sclerosis has been found to correlate with cortical atrophy, especially in superior frontal, superior parietal, and temporal areas. ${ }^{29-31}$ These studies support our hypothesis that depression in multiple sclerosis could have an underlying cortical mechanism and such a mechanism might be of particular importance in patients with multiple sclerosis who present with predominant cognitive symptoms.

\section{Cognitive presentation of multiple sclerosis}

Progressive impairment in more than one domain of intellectual function without alteration in arousal (dementia) may result from cortical or subcortical dysfunction. Cortical 
Table 2 Demographic and clinical summary of previously reported cases of cortical multiple sclerosis

\begin{tabular}{|c|c|c|c|c|}
\hline $\begin{array}{l}\text { Ref } \\
\text { No }\end{array}$ & Age/sex & Initial presentation & Paraclinical finding & Follow up period after presentation and progress \\
\hline \multirow[t]{3}{*}{13} & $19 / \mathrm{F}$ & $\begin{array}{l}\text { Subacute onset of intermittent } \\
\text { confusion plus social withdrawal } \\
\text { and epilepsy }\end{array}$ & VER: delayed; CSF: pleocytosis & $\begin{array}{l}5 \text { years; bilateral optic atrophy, complete deafness, } \\
\text { hemi-pyramidal weakness, reduced sensation on T10 to L4 } \\
\text { distribution bilaterally }\end{array}$ \\
\hline & $23 / \mathrm{F}$ & $\begin{array}{l}\text { Subacute episode of depression, } \\
\text { leading to mutism and change in } \\
\text { personality }\end{array}$ & $\begin{array}{l}\text { VER: delayed; CSF: pleocytosis, } \\
\text { increased lgG; EEG: bilateral slow } \\
\text { waves }\end{array}$ & $\begin{array}{l}2 \text { years; ataxia and sphincter involvement responded to } \\
\text { steroids with complete recovery within } 4 \text { months; developed } \\
\text { sensory and visual symptoms plus extensor plantar responses }\end{array}$ \\
\hline & $24 / F$ & $\begin{array}{l}\text { Depression plus disorientation } \\
\text { associated with poor memory and } \\
\text { lack of insight }\end{array}$ & $\begin{array}{l}\text { VER: delayed; CSF: high protein; CT } \\
\text { or MRI (?): cerebral atrophy and low } \\
\text { density periventricular flares; EEG: } \\
\text { bilateral slow waves }\end{array}$ & $\begin{array}{l}7 \text { years; impaired verbal and performance } I Q \text {, change in } \\
\text { personality, recovered over } 7 \text { months; developed a subacute } \\
\text { amnesia plus epilepsy, dysgraphia, and hemipyramidal } \\
\text { weakness }\end{array}$ \\
\hline \multirow[t]{5}{*}{14} & $30 / \mathrm{F}$ & $\begin{array}{l}\text { Anxiety, depression, reduced } \\
\text { global cognitive function }\end{array}$ & $\begin{array}{l}\text { VER: not done; CSF: increased lgG; } \\
\text { LAEG: cortical atrophy; EEG: bilateral } \\
\text { slow waves }\end{array}$ & $\begin{array}{l}4 \text { years; reduced verbal and performance } I Q \text {, dysphagia, } \\
\text { diplopia and urinary incontinence. Bilateral optic atrophy, } \\
\text { nystagmus, dysarthria, bilateral facial palsy, hyper-reflexia } \\
\text { and ataxia. }\end{array}$ \\
\hline & $35 / M$ & $\begin{array}{l}\text { Anxiety, depression, clumsiness, } \\
\text { slurred speech, poor memory, } \\
\text { euphoria }\end{array}$ & $\begin{array}{l}\text { VER: not done; CSF: increased lgG; } \\
\text { LAEG: cortical atrophy }\end{array}$ & $\begin{array}{l}1 \text { year; bilateral optic atrophy, vertical nystagmus, long tract } \\
\text { signs cerebellar ataxia reduced verbal intelligence, } \\
\text { progressive amnesia }\end{array}$ \\
\hline & $40 / M$ & $\begin{array}{l}\text { Episodes of anxiety, depression, } \\
\text { perseveration, poor attention, } \\
\text { memory deficit, dysgraphia }\end{array}$ & $\begin{array}{l}\text { VER: not done; CSF: increased lgG; } \\
\text { LAEG: cortical atrophy; EEG: bilateral } \\
\text { slow waves }\end{array}$ & $\begin{array}{l}12 \text { years; facial palsy, slurred speech and gait ataxia, } \\
\text { dizziness, nystagmus, clumsiness, dyscalculia, quadriparetic } \\
\text { spasticity }\end{array}$ \\
\hline & $35 / M$ & $\begin{array}{l}\text { Depression, poor memory, } \\
\text { inappropriate hunger, aggressive } \\
\text { behaviour }\end{array}$ & $\begin{array}{l}\text { VER: not done; CSF: increased lgG } \\
\text { and pleocytosis; LAEG: cortical } \\
\text { atrophy; EEG: bilateral slow waves }\end{array}$ & $\begin{array}{l}8 \text { months; optic atrophy, gait ataxia, progressive cognitive } \\
\text { impairment, dyscalculia, dysphasia, lack of insight, reduced } \\
\text { verbal and performance intelligence, severe memory } \\
\text { impairment, nominal dysphasia }\end{array}$ \\
\hline & $39 / M$ & $\begin{array}{l}\text { "Hysterical" type symptoms, } \\
\text { progressive psychotic depression, } \\
\text { limb trembling }\end{array}$ & $\begin{array}{l}\text { VER: not done; CSF: increased lgG; } \\
\text { LAEG: cortical atrophy }\end{array}$ & $\begin{array}{l}9 \text { years; optic atrophy, dyslexia, limb ataxic, long tract signs, } \\
\text { progressive cognitive impairment characterised by impaired } \\
\text { memory and non-verbal cognitive skills }\end{array}$ \\
\hline \multirow[t]{3}{*}{15} & $41 / \mathrm{F}$ & Depression & $\begin{array}{l}\text { VER: not done; CSF: increased lgG; } \\
\text { no imaging }\end{array}$ & $\begin{array}{l}5 \text { years; nystagmus, cerebellar signs, neuropsychological } \\
\text { deficit (dyspraxia and somatognosia) suggesting cortical } \\
\text { dysfunction }\end{array}$ \\
\hline & $33 / F$ & $\begin{array}{l}\text { Depression, "histrionic" } \\
\text { personality }\end{array}$ & $\begin{array}{l}\text { VER: not done; CSF: increased lgG; } \\
\text { no imaging }\end{array}$ & $\begin{array}{l}15 \text { years; optic neuritic, neuropsychological deficit including } \\
\text { constructional apraxia suggesting cortical dysfunction }\end{array}$ \\
\hline & $32 / \mathrm{F}$ & $\begin{array}{l}\text { Depression, medically } \\
\text { "unexplained" symptoms, eg, } \\
\text { dizziness, blurred vision, "off } \\
\text { balance" with no neurological } \\
\text { signs }\end{array}$ & $\begin{array}{l}\text { VER: not done; CSF: increased lgG; } \\
\text { no imaging }\end{array}$ & $\begin{array}{l}\text { Nystagmus, cerebellar ataxia, neuropsychological deficit } \\
\text { suggesting right temporo-parietal dysfunction }\end{array}$ \\
\hline 16 & $37 / M$ & $\begin{array}{l}\text { Depression, memory loss } \\
\text { (Korsakoff type) }\end{array}$ & $\begin{array}{l}\text { VER: delayed; CSF: OCB-; MRI (10 } \\
\text { years after initial presentation): } \\
\text { bilateral high signal in temporal lobes } \\
\text { and periventricular area }\end{array}$ & $\begin{array}{l}13 \text { years; cognitive impairment, personality change, INO, } \\
\text { ataxia, incontinence, visual loss }\end{array}$ \\
\hline 17 & $37 / F$ & Depression & $\begin{array}{l}\text { VER: delayed; CSF: OCB+; MRI: } \\
\text { cerebral atrophy + WM high signal } \\
\text { changes }\end{array}$ & $\begin{array}{l}8 \text { months; impaired visuospatial skills, frontal lobe dysfunction, } \\
\text { impaired abstract thinking, concept formation, judgment, } \\
\text { apraxis, poor attention, long tract signs, posterior column signs }\end{array}$ \\
\hline \multirow[t]{2}{*}{18} & $41 / M$ & $\begin{array}{l}\text { Change in personality, } \\
\text { forgetfulness, labile indifference } \\
\text { and poor verbal memory }\end{array}$ & $\begin{array}{l}\text { VER: delayed; CSF: OCB+, MRI: WM } \\
\text { high signal changes; EEG: diffuse slow } \\
\text { activity }\end{array}$ & $\begin{array}{l}8 \text { years; impaired verbal fluency, impaired verbal and } \\
\text { performance } I Q \text {, visuospatial deficit, left/right disorientation, } \\
\text { dyscalculia, dysgraphia, urinary incontinence, wheelchair } \\
\text { bound and incontinent }\end{array}$ \\
\hline & $35 / M$ & $\begin{array}{l}\text { Memory decline, poor } \\
\text { concentration }\end{array}$ & $\begin{array}{l}\text { VER: delayed; CSF: OCB+; MRI: WM } \\
\text { high signal changes; EEG: diffuse slow } \\
\text { activity }\end{array}$ & $\begin{array}{l}4.5 \text { years; personality change, poor verbal memory, } \\
\text { dyscalculia, reduced verbal fluency, bilateral optic atrophy, } \\
\text { gait ataxia, severe cognitive impairment }\end{array}$ \\
\hline 19 & $43 / M$ & $\begin{array}{l}\text { Acute onset of psychotic } \\
\text { depression leading to attempted } \\
\text { suicide }\end{array}$ & $\begin{array}{l}\text { VER: delayed; CSF: OCB+; MRI: WM } \\
\text { high signal changes }\end{array}$ & $\begin{array}{l}3 \text { months; responded to intravenous methylprednisolone, } \\
\text { nystagmus, extensor plantar respnses }\end{array}$ \\
\hline 20 & $43 / F$ & $\begin{array}{l}\text { Depression leading to suicidal } \\
\text { attempt, impaired remote memory }\end{array}$ & $\begin{array}{l}\text { VER: delayed; CSF: OCB +; MRI: } \\
\text { cerebral atrophy + WM changes }\end{array}$ & 2.5 years; long tract signs, gait ataxia, sphincter involvement \\
\hline
\end{tabular}

$C S F$, cerebrospinal fluid; $C T$, computed tomography; $E E G$, electroencephalogram; $F$, female; $I N O$, internuclear ophthalmoplegia; $I Q$, intelligence quotient; LAEG, lumbar air encephalogram; M, male; MRI, magnetic resonance imaging; OCB, oligoclonal bands; VER, visual evoked response; WM, white matter.

dementias are classically associated with dysphasia, dyscalculia, dyspraxia, agnosia, and severe amnesia in the absence of significant primary sensorimotor dysfunction. ${ }^{32}$ Subcortical dementia is characterised by early psychomotor retardation and mood disturbance, with relative preservation of language, calculation, and object recognition, and by memory deficit which is greatest in free recall tasks, improving with cueing and recognition paradigms. ${ }^{33}$

Although regarded as a typical subcortical dementia, ${ }^{34}{ }^{35}$ a subgroup of patients with multiple sclerosis shows marked impairment of abstract-conceptual reasoning, dependent on intact frontal functions ${ }^{34}$ and impaired language, ${ }^{5}$ suggesting cortical dysfunction. In addition, memory impairment is a common complaint in patients with multiple sclerosis and was a prominent feature in our cases. Moriarty and colleagues $^{36}$ showed a strong correlation between reduced performance on the Rey auditory verbal learning test and the number of cortical lesions detected with Fast FLAIR (fluid attenuated inversion recovery) images (detecting 154 lesions at the cortical/juxtacortical area compared with 10 using conventional imaging). These investigators concluded that cortical lesions in patients with multiple sclerosis correlate 
with impaired retention of information in memory tasks. In another study, PET imaging showed hypofunction of the hippocampus, cingulate gyrus, associative occipital cortex, prefrontal cortex, and inferior parietal cortex in patients with multiple sclerosis and memory impairment. ${ }^{37}$ Bilateral hippocampal hypometabolism in these patients correlated with impairment of episodic memory, suggesting that the amnesic syndrome in multiple sclerosis is the direct result of cortical involvement. A recent study has shown that impairment of verbal learning, spatial learning, attention, and conceptual reasoning correlates with bilateral superior frontal cortices dysfunction. $^{38}$

\section{Cortical pathology in multiple sclerosis}

The relatively few neuropathological studies of cortical lesions in multiple sclerosis have not sought to establish correlations with cognitive impairment. In Brownell and Hughes' study ${ }^{39}$ $5 \%$ of lesions were cortical but these all came from one of their 22 cases. In contrast, Lumsden ${ }^{40}$ reported that cortical involvement occurred in $93 \%$ of patients with multiple sclerosis. Most cortical lesions in these studies were at the white-grey matter junction. More recently, Kidd and colleagues ${ }^{41}$ studied cortical lesions in multiple sclerosis and categorised these into four groups according to cortical vasculature. They provide some evidence that intracortical lesions are located around the intracortical vein (V4), in contrast to juxtacortical lesions that are associated with gyral veins located at the white-grey matter junction. Peterson and colleagues ${ }^{42}$ studied 112 cortical lesions which were identified in 110 tissue blocks from 50 patients with multiple sclerosis, and showed that cortical lesions contained 13 times fewer $\mathrm{CD} 3$ positive lymphocytes and six times fewer CD68 positive microglia/macrophages than subcortical lesions.

Taken together, these and other studies support the existence of multiple sclerosis with exclusive or predominant cortical lesions. It does not, however, necessarily follow that these lesions correlate with symptoms, either at presentation or later in the clinical course of the disease. This remains to be demonstrated.

\section{Radiological evidence for cortical involvement in multiple sclerosis}

Several workers have tried, with limited success, to correlate neuropsychiatric symptoms in multiple sclerosis with cortical $^{43}$ or white matter ${ }^{44}$ lesion load. The lack of success may reflect the limitations in imaging methods for identifying cortical lesions in multiple sclerosis, and the variability of neuropsychological methods used to identify cognitive deficits. The former problem arises from the fact that the cerebral cortex has a longer relaxation time than white matter during MRI. This reduces the resolution and contrast of lesions against background grey matter on conventional T2W MRI. ${ }^{41}$ Catalaa and colleagues ${ }^{43}$ used conventional MRI with locally designed software to detect cortical lesions, but failed to correlate global cognitive function with cortical lesions found in 18 patients with multiple sclerosis. However, their study does not exclude a correlation between neuropsychological performance on specific tests relevant to temporal and frontal systems with cortical lesions.

Recent advances in imaging techniques inform this debate. Boggild et al showed that cortical lesions in multiple sclerosis, not visible on conventional T2W images, could be seen using FLAIR imaging with prolonged inversion time.$^{45}$ Rovaris et al used RARE (dual echo rapid acquisition with relaxation enhancement) and fast FLAIR to show that total cortical lesion loads are significantly greater in cognitively impaired patients. ${ }^{46}$ They also showed that average cortical/juxtacortical magnetisation transfer ratio (MTR) is the only parameter strongly associated with cognitive impairment. Lazeron and colleagues ${ }^{47}$ used a similar protocol and found that the number of non-cortical lesions correlated with the expanded disability status scale, whereas the number of cortical/juxtacortical lesions correlated with cognitive impairment index. In another study, biochemical abnormality in cerebral cortex was detected in patients with relapsing-remitting multiple sclerosis even in the absence of cortical lesion on conventional brain MRI. ${ }^{48}$

More specific evidence for early involvement of the cerebral cortex in multiple sclerosis is provided by Sokic et al, ${ }^{49}$ who used brain MRI with gadolinium pentetate dimeglumine and found that multiple sclerosis presenting with seizures is associated with cortical plaques in anatomical areas that explain clinical and electrophysiological features of the seizure disorder. Collectively, these recent studies suggest that cortical lesions can be identified with increased reliability and correlated with specific cortical syndromes. Cortical atrophy, believed to represent axonal loss, ${ }^{50-54}$ is also often present in multiple sclerosis at the time of diagnosis ${ }^{55}$ and may be visualised using newer imaging techniques. ${ }^{56}{ }^{57}$ Improved detection of cortical lesions using these recently developed imaging techniques has yet to be systematically correlated with specific neuropsychological deficits.

\section{Conclusions}

Although it is difficult to distinguish the contributions of white and grey matter lesions to cognitive symptomatology in multiple sclerosis, we believe that the neuropsychiatric presentations described, along with well documented examples of focal cortical syndromes such as aphasia, epilepsy, and cortical sensory loss, support our hypothesis of a cortical variant of multiple sclerosis. It follows, therefore, that multiple sclerosis should be considered in the differential diagnosis of unusual and intractable depression as well as in dementiaparticularly with cortical features-even in the absence of hard neurological signs. While depression appears to be the most common cortical presentation of multiple sclerosis, to screen all patients with depression for ancillary evidence of this disease would be inefficient and a poor use of finite resources. Therefore, we suggest that routine questioning and physical examination for possible evidence of cryptic demyelination should be part of the routine assessment of patients who present with depression or early onset dementia. Consideration of paraclinical investigations that support the diagnosis of multiple sclerosis and formal neuropsychological assessment should be undertaken, especially in younger patients with cognitive abnormalities.

\section{Authors' affiliations}

M Zarei, S Chandran, A Compston, J Hodges, Department of Neurology, University of Cambridge, Addenbrooke's Hospital, Cambridge, UK

Competing interests: none declared

\section{REFERENCES}

1 McDonald WI, Compston A, Edan G, et al. Recommended diagnostic criteria for multiple sclerosis: guidelines from the international panel on the diagnosis of multiple sclerosis. Ann Neurol 2001;50:121-7.

2 Kurtzke JF. Rating neurologic impairment in multiple sclerosis: an expanded disability status scale (EDSS). Neurology 1983;33: 1444-52.

3 Brassington JC, Marsh NV. Neuropsychological aspects of multiple sclerosis. Neuropsychol Rev 1998:8:43-77.

4 Rao SM. Neuropsychology of multiple sclerosis. Curr Opin Neurol 1995;8:216-20.

5 Peyser JM, Rao SM, LaRocca NG, et al. Guidelines for neuropsychological research in multiple sclerosis. Arch Neurol 1990:47:94-7.

6 Lyon-Caen O, Jouvent R, Hauser S, et al. Cognitive function in recent-onset demyelinating diseases. Arch Neurol 1986;43:1 138-41.

7 Swingler RJ, Compston DA. The morbidity of multiple sclerosis. Q J Med 1992:83:325-37.

8 Truelle JL, Palisson E, Le Gall D, et al. Intellectual and mood disorders in multiple sclerosis. Rev Neurol (Paris) 1987;143:595-601. 
9 Ron MA, Callanan MM, Warrington EK. Cognitive abnormalities in multiple sclerosis: a psychometric and MRI study. Psychol Med 1991;21:59-68

10 Feinstein A, Youl B, Ron M. Acute optic neuritis. A cognitive and magnetic resonance imaging study. Brain 1992;115:1403-15.

11 Feinstein A, Ron M, Thompson A. A serial study of psychometric and magnetic resonance imaging changes in multiple sclerosis. Brain 1993; 1 16:569-602

12 Skegg K. Multiple sclerosis presenting as a pure psychiatric disorder. Psychol Med 1993;23:909-14.

13 Matthews WB. Multiple sclerosis presenting with acute remitting psychiatric symptoms. I Neurol Neurosurg Psychiatry 1979;42:859-63.

14 Young AC, Saunders J, Ponsford JR. Mental change as an early feature of multiple sclerosis. J Neurol Neurosurg Psychiatry 1976;39:1008-13.

15 Goodstein RK, Ferrell RB, Multiple sclerosis - presenting as depressive illness. Dis Nerv Syst 1977;38:127-31.

16 Vighetto A, Charles N, Salzmann M, et al. Korsakoff's syndrome as the initial presentation of multiple sclerosis. J Neurol 1991;238:351-4

17 Averbuch-Heller L, Shalev AY, Abramowitz MZ. An unusual presentation of multiple sclerosis. Am J Psychiatry 1992;149:410-11.

18 Hotopf MH, Pollock S, Lishman WA. An unusual presentation of multiple sclerosis. Psychol Med 1994;24:525-8

19 Clarke T, Wadhwa U, Leroi I. Psychotic depression. An atypical initial presentation of multiple sclerosis. Psychosomatics 1998;39:72-5.

20 Salloway S, Price LH, Charney DS, et al. Multiple sclerosis presenting as major depression: a diagnosis suggested by MRI scan but not CT scan. J Clin Psychiatry 1988;49:364-6.

21 Minden SL, Schiffer RB. Affective disorders in multiple sclerosis. Review and recommendations for clinical research. Arch Neurol 1990;47:98-104.

22 Whitlock FA, Siskind MM. Depression as a major symptom of multiple sclerosis. J Neurol Neurosurg Psychiatry 1980;43:861-5

23 McDonald WI, Ron MA. Multiple sclerosis: the disease and its manifestations. Philos Trans R Soc Lond B Biol Sci 1999;354:1615-22.

24 Drevets WC. Functional anatomical abnormalities in limbic and prefrontal cortical structures in major depression. Prog Brain Res 2000;126:413-31

25 Baxter LR, Schwartz JM, Phelps ME, et al. Reduction of prefrontal cortex glucose metabolism common to three types of depression. Arch Gen Psychiatry 1989;46:243-50.

26 Mayberg HS, Starkstein SE, Sadzot B, et al. Selective hypometabolism in the inferior frontal lobe in depressed patients with Parkinson's disease. Ann Neurol 1990;28:57-64.

27 Wu JC, Gillin JC, Buchsbaum MS, et al. Effect of sleep deprivation on brain metabolism of depressed patients. Am J Psychiatry 1992;149:538-43

28 Sabatini U, Pozzilli C, Pantano P, et al. Involvement of the limbic system in multiple sclerosis patients with depressive disorders. Biol Psychiatry 1996:39:970-5.

29 Bakshi R, Czarnecki D, Shaikh ZA, et al. Brain MRI lesions and atrophy are related to depression in multiple sclerosis. Neuroreport 2000;11:1153-8.

30 Janardhan V, Bakshi R. Quality of life and its relationship to brain lesions and atrophy on magnetic resonance images in 60 patients with multiple sclerosis. Arch Neurol 2000:57:1485-91.

31 Zivadinov R, Sepcic J, Nasuelli D, et al. A longitudinal study of brain atrophy and cognitive disturbances in the early phase of relapsing-remitting multiple sclerosis. J Neurol Neurosurg Psychiatry 2001;70:773-80.

32 Huber SJ, Shuttleworth EC. Neuropsychological assessment of subcortical dementia. In: Cumming JL, ed. Subcortical dementias. Oxford: Oxford University Press, 1990:71-86.

33 Salmon DP, Hodges JR. Neuropsychological assessment of early onset dementia. In: Hodges JR, ed. Early-onset dementia. Oxford: Oxford University press, 2001:47-73.

34 Rao SM. Multiple sclerosis. In: Cumming JL, ed. Subcortical dementias. Oxford: Oxford University Press, 1990: 164-80.
35 Wilson HC, Scolding NJ, Inflammatory and infective disorders. In: Hodges JR, ed. Early-onset dementia. Oxford: Oxford University press, 2001:385-7

36 Moriarty DM, Blackshaw AJ, Talbot PR, et al. Memory dysfunction in multiple sclerosis corresponds to juxtacortical lesion load on fast fluid-attenuated inversion-recovery MR images. Am J Neuroradiol 1999:20: 1956-62

37 Paulesu E, Perani D, Fazio F, et al. Functional basis of memory impairment in multiple sclerosis: an [18F]FDG PET study. Neuroimage 1996;4:87-96

38 Benedict RH, Bakshi R, Simon JH, et al. Frontal cortex atrophy predicts cognitive impairment in multiple sclerosis. J Neuropsychiatry Clin Neurosci 2002; 14:44-51.

39 Brownell B, Hughes JT, The distribution of plaques in the cerebrum in multiple sclerosis. J Neurol Neurosurg Psychiatry 1962;25:315-20.

40 Lumsden CE. The neuropathology of multiple sclerosis. In: Vinken PJ, Bruyn GW, eds. Handbook of clinical neurology, vol 9. Amsterdam: Elsevier, 1970: 217-309.

41 Kidd D, Barkhof F, McConnell R, et al. Cortical lesions in multiple sclerosis. Brain 1999;122:17-26.

42 Peterson JW, Bo L, Mork S, et al. Transected neurities, apoptotic neurons, and reduced inflammation in cortical multiple sclerosis lesions. Ann Neurol 2001:50:389-400.

43 Catalaa I, Fulton JC, Zhang X, et al. MR imaging quantitation of gray matter involvement in multiple sclerosis and its correlation with disability measures and neurocognitive testing. Am J Neuroradiol 1999:20:1613-18.

44 Camp SJ, Stevenson VL, Thompson AJ, et al. Cognitive function in primary progressive and transitional progressive multiple sclerosis: a controlled study with MRI correlates. Brain 1999;122:1341-8.

45 Boggild MD, Williams R, Haq N, et al. Cortical plaques visualised by fluid-attenuated inversion recovery imaging in relapsing multiple sclerosis. Neuroradiology 1996;38(suppl 1):S10-13.

46 Rovaris M, Filippi M, Minicucci L, et al. Cortical/subcortical disease burden and cognitive impairment in patients with multiple sclerosis. Am J Neuroradiol 2000;21:402-8.

47 Lazeron RH, Langdon DW, Filippi $M$, et al. Neuropsychological impairment in multiple sclerosis patients: the role of (juxta) cortical lesion on FLAIR. Multiple Sclerosis 2000:6:280-5.

48 Sharma R, Narayana PA, Wolinsky JS. Grey matter abnormalities in multiple sclerosis: proton magnetic resonance spectroscopic imaging. Multiple Sclerosis 2001;7:221-6.

49 Sokic DV, Stojsavlievic N, Drulovic J, et al. Seizures in multiple sclerosis. Epilepsia 2001;42:72-9.

50 Trapp BD, Ransohoff R, Rudick R. Axonal pathology in multiple sclerosis: relationship to neurologic disability. Curr Opin Neurol 1999; 12:295-302

51 Rudick RA, Fisher E, Lee JC, et al. Use of the brain parenchymal fraction to measure whole brain atrophy in relapsing-remitting MS. Multiple Sclerosis Collaborative Research Group. Neurology 1999;53:1698704.

52 Simon JH. Brain and spinal cord atrophy in multiple sclerosis. Neuroimaging Clin N Am 2000;10:753-70.

53 Simon JH. From enhancing lesions to brain atrophy in relapsing MS. $J$ Neuroimmunol 1999:98:7-15.

54 Simon JH, Jacobs LD, Campion MK, et al. A longitudinal study of brain atrophy in relapsing multiple sclerosis. The Multiple Sclerosis Collaborative Research Group (MSCRG). Neurology 1999;53:139-48.

55 Bakshi R, Benedict RH, Bermel RA, et al. Regional brain atrophy is associated with physical disability in multiple sclerosis: semiquantitative magnetic resonance imaging and relationship to clinical findings. $J$ Neuroimaging 2001;11:129-36.

56 Bakshi R, Shaikh ZA, Janardhan V. MRI T2 shortening ("black T2") in multiple sclerosis: frequency, location, and clinical correlation. Neuroreport 2000;11:15-21.

57 Bakshi R, Dmochowski J, Shaikh ZA, et al. Gray matter T2 hypointensity is related to plaques and atrophy in the brains of multiple sclerosis patients. J Neurol Sci 2001;185:19-26. 